\title{
Brazilian attitudes towards the use of animals in research
}

\section{Atitudes de brasileiros no uso de animais em pesquisa}

\author{
Ana Paula Oliveira SOUZA'; Carla Forte Maiolino MOLENTO ${ }^{1}$; Vanessa Carli BONES ${ }^{1}$; \\ Jaqueline QUADROS ${ }^{1}$; Catherine Anne SCHUPPLI'² Daniel Martin WEARY ${ }^{3}$ \\ ${ }^{1}$ Universidade Federal do Paraná, Laboratório de Bem-estar Animal, Curitiba - PR, Brazil \\ ${ }^{2}$ University of British Columbia, Vancouver - BC, Canada \\ ${ }^{3}$ University of British Columbia, Faculty of Land and Food Systems, Vancouver - BC, Canada
}

\begin{abstract}
Little research has examined the views of Latin Americans on the use of animals in research. This study examined the degree to which Brazilians support the use of animals in research and the reasons they put forth to explain their position. Participants were randomly assigned to research scenarios describing the use of animals for biomedical or environmental benefits, and varying in the number of pigs required. Each scenario began by proposing the use of conventional pigs and then advanced to the development and use of genetically modified animals (GMA). A total of 151 quantitative and 307 qualitative answers were analysed. Scenario and number of animals had little effect on support, but opposition increased from $25 \%$ to $58 \%$ when pigs were used to develop a GM strain for the environmental scenario. Support to use of animals was often conditional upon adequate protection of the animals' welfare. Participants were less willing to support research on environmental scenario when this involved the creation of GMA, in part because they feared the risk associated with this technology.
\end{abstract}

Keywords: Animal ethics. Animal welfare. Animal experimentation. Genetic engineering.

\section{Resumo}

Há poucos estudos sobre a opinião de latino-americanos quanto ao uso de animais em pesquisa. Este estudo avaliou o grau de apoio e as motivações de brasileiros em relação a essa questão. Os participantes foram aleatoriamente apresentados a dois cenários, um biomédico e outro ambiental, variando também o número de animais usados. Cada cenário se iniciava com o uso de suínos convencionais e prosseguia com o desenvolvimento e uso de animais geneticamente modificados. Foram analisadas 151 respostas quantitativas e 307 qualitativas. O cenário e o número de animais tiveram pouco efeito no apoio ao uso dos animais, no entanto, a oposição aumentou de $25 \%$ para $58 \%$ quando o uso de suínos geneticamente modificados foram apresentados no cenário ambiental. $\mathrm{O}$ apoio ao uso de animais em pesquisa estava frequentemente condicionado ao grau de bem-estar animal, e o apoio à pesquisa diminuiu com o uso de animais geneticamente modificados, em parte, devido aos riscos associados a essa tecnologia.

Palavras-chave: Ética animal. Bem-estar animal. Experimentação animal. Engenharia genética.

Correspondence to:

Carla Forte Maiolino Molento

Rua dos Funcionários, 1540

CEP 80035-050, Curitiba, PR, Brasil

e-mail: carlamolento@ufpr.br

Received: $16 / 4 / 2016$

Approved: 12/5/2017

\section{Introduction}

The use of animals in research is widespread, as is public criticism of this form of animal use (ROLLIN, 2003). The total number of animals used for experimental and other scientific purposes in Member States of the European Union (EU) in 2008 was twelve million (EUROPEAN COMMISSION, 2010b). Little data is available for much of Latin America. In Brazil, there is no official reporting of the number of animals used in research. One recent study attempted to estimate numbers using bibliographic methods, and calculated that 216,223 vertebrates were used in research in 2006 in just one of the twenty-seven Brazilian states (SILLA et al., 2010), and Taylor et al. (2008) estimated a total of 1.2 million vertebrates. 
In response to public concerns, some countries have developed policies that regulate the treatment of animals in research (OLFERT et al., 1993; EUROPEAN COMMISSION, 2010b), and some have also monitored public opinion related to animal use and in particular to biotechnology such as genetic modification (EUROPEAN COMMISSION, 2010a). In Brazil, the Arouca Act (BRASIL, 2008) established the National Council for the Control of Animal Experimentation (CONCEA) and required research and teaching institutions to establish an ethics committee on the use of animals. The Brazilian Environmental Act (BRASIL, 1998) established penalties for using animals in experiments if alternative methods are available, although enforcement appears to be lax (BONES et al., 2014).

The use of genetically modified (GM) animals in research is increasing rapidly (ORMANDY et al., 2009), and some of this research has targeted farm animals. In Brazil, the Recodisa Project genetically modified goats to produce milk with human enzyme lyzesome, useful for treating childhood diarrhea (CARVALHO et al., 2012). However, there are a number of public concerns about the use of GM animals, including perceived risks associated with this technology (FREWER, 2004). The objectives of this paper were to describe the range of views of Brazilian participants on use of animals in biomedical and environmental research, and determine the reasons the participants put forth to explain their position.

\section{Material and Methods}

This study was approved by the Behavioural Research Ethics Board at the University of British Columbia (H0680532).

\section{Survey design}

An interactive online engagement tool designed to investigate public perceptions of new technologies was used. Following Schuppli et al. (2013) study, participants were asked their views on the use of domestic pigs for research in order to improve organ transplant success in humans (the biomedical scenario, BS) and to reduce agricultural pollution (the environmental scenario, ES). The species was selected because it fits both scenarios, since pigs are widely used for human consumption and medical research worldwide. In addition, as a domestic animal, pigs would be familiar to most respondents.
Both scenarios included a proposal to create or use genetically modified pigs, and the ES also included a proposal to feed pigs GM corn. The proposed number of pigs varied from ten to 1000. Participants were randomly assigned to a scenario and a proposed number of pigs. After they were introduced to the study goals, demographic information was requested and a series of three questions was presented, asking participants to indicate their level of support for this use of pigs using a six-point Likert scale (strong yes, weak yes, neutral, weak no, strong no, undecided). In the BS the following series of questions were proposed: 'Would you support the use of (X) pigs (where $\mathrm{X}=$ ten, 100 or 1000) for research on organ rejection', 'Would you support the use of $(\mathrm{X})$ pigs to develop a genetically modified strain for research on organ rejection?' and 'Would you support the use of $(\mathrm{X})$ genetically modified pigs for research on organ rejection?'. In the ES, the following questions were proposed: 'Would you support the use of (X) pigs for research to reduce phosphorus pollution from pig farms', 'Would you support the use of (X) pigs for research to reduce phosphate pollution by feeding the pigs genetically modified corn' and 'Would you support the use of (X) pigs to develop a genetically modified pig to reduce phosphorus pollution from pig farms?' Following each question, participants were provided with an open-ended text box and invited to explain their answers. All quotes presented were translated from Portuguese by the first and second authors.

\section{Participant recruitment}

Participants were recruited using two methods. First, through e-mail messages to colleagues in veterinary medicine and animal science programs working in Brazilian universities, and from personal contacts, obtained from the Ministry of Education (MEC) (http:// portal.mec.gov.br/sesu/) and the Federal Veterinary Medicine Council (CFMV) (http://www.cfmv.org.br/ portal/index.php) websites. Second, from personal contacts, through a variant of the purposive sampling, known as snowball sampling (PALYS, 2003). The intention was not to collect a random or representative sample of members of public, but rather to focus on individuals aware of animal issues. Data collection took place from November 2008 to April 2009. A total of 210 participants answered the first question (106 on BS and 104 on ES). This number decreased to 175 ( 87 on BS and 88 on ES) 
on the second question and 151 on the third question (78 on BS and 73 on ES). Most respondents were from Brazil (96.6\%), were young $(64.4 \%, 19-29$ years), female (55.7\%), well educated (56.4\% graduate and $32.8 \%$ post-graduate level), were currently or had been pet owners (98.8\%) and ate meat $(88.4 \%)$. About $82.3 \%$ of respondents considered themselves familiar with animal research, 36.0\% with genetic modification, $92.5 \%$ with animal welfare, and $89.1 \%$ with ethical issues.

\section{Statistical analyses of quantitative data}

Only participants who answered all the three questions were considered in this analysis. To evaluate the level of support of respondents, strong yes and weak yes answers were considered as supportive, and strong no and weak no were considered as nonsupportive. Kruskal-Wallis test was used to compare responses between scenarios. A chi-square test was used to compare responses between questions within each scenario and according to the number of animals in each question.

\section{Analysis of qualitative data}

Participants who answered one, two or all three questions were included in the qualitative analysis. First, comments were compared to Likert responses and classified as: support regardless of other factors (SR), conditional support (CS), no support (NS), and uncertain or indifference (UN). Comments were grouped into themes extracted from respondents' answers following the methods described by Knight and Barnett (2008). All themes were evaluated according to the emphasis given by the respondents, and one comment can have more than one identified theme.

\section{Results and Discussion}

\section{Quantitative results}

We analyzed responses from 151 participants (51\% from the BS and $49 \%$ from the ES). The level of support for the use of animals in research of 55\% in the current study was similar to that reported elsewhere in the literature. For example, the support in other studies ranged from $30 \%$ to $70 \%$ (CRETTAZ VON ROTEN, 2009, 2012; IPSOS MORI, 2012). Schuppli et al. (2013) found similar levels of support to the identically worded BS, despite using English speaking respondents, mostly from Canada and the United States. The similarity in support in these two studies is not consistent with the work of Franzen and Meyer (2010) who claimed that public attitudes towards animal research was higher in industrialised versus postindustrialised countries.

For the BS, 28\% were opposed to the proposed research when it involved non-GM animals (Question 1), but opposition tended to increase to $41 \%$ when the research proposed the creation of a new line of GM pig (Question 2, $\mathrm{P}=0.09$ ) and to $42 \%$ with the use of GM pigs (Question 3, $\mathrm{P}=0.057$ ) (Figure 1). For the ES, 25\% were opposed to the proposed research when it involved non-GM animals (Question 1). Opposition tended to increase to 37\% when the research proposed the use feeding pigs of GM corn (Question 2, P = 0.07) and increased further to 58\% with the creation of a new line of GM pigs (Question 3, P < 0.0001).

There was no difference between the two scenarios for opposition to the use of non-GM animals (Question 1 in both scenarios; $P=0.157$ ). In contrast, Schuppli et al. (2013) found that mostly North American participants were more supportive of the use of non-GM pigs for the ES than for the biomedical use. According to Franzen and Meyer (2010) and Crettaz von Roten (2012), respondents from richer countries typically report higher levels of environmental concern. With the creation of a new line of GM pigs, fewer respondents were opposed in the BS compared to the ES ( $41 \%$ in Question 2 in the BS versus $58 \%$ in Question 3 in the ES; $\mathrm{P}=0.02$ ), which means that participants were also more cautious about the use of the GM pigs in the ES. As argued by Schuppli et al. (2013), these effects may be based on concerns about pigs intended for human consumption. People often avoid foods that they associate with negative attributes, including beliefs about negative impacts on the environment and risks to human or animal health (FREWER et al., 2004).

Our results showed only a weak effect of the number of animals on participant support. For the BS, level of opposition was higher to 1000 animals compared to ten and 100 for Question $1(\mathrm{P}=0.009, \mathrm{P}=0.002)$; and was higher for ten and 1000 animals compared to 100 for Question 3 ( $\mathrm{P}=0.03, \mathrm{P}=0.02$ ). For the ES, the level of opposition was higher for 100 animals compared to ten and 1000 for Question $1(\mathrm{P}=0.018, \mathrm{P}=0.009)$. Crettaz von Roten (2012) found that acceptance of animal use for medical research was not related to the number of animals used. Schuppli et al. (2013) also found little influence of numbers of research animals on attitudes. 


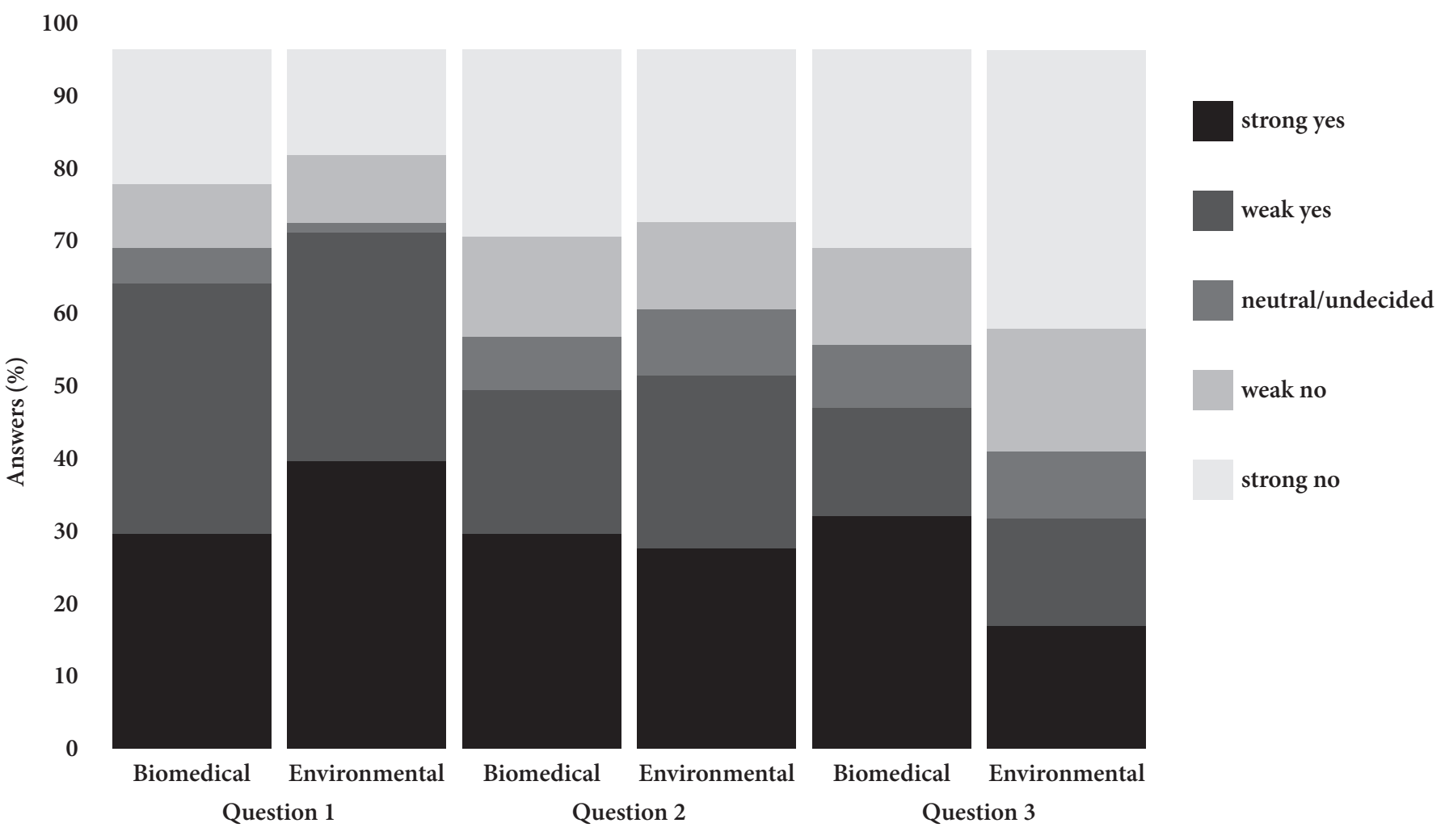

Figure 1 - Percentage of Brazilian respondents in the biomedical scenario (78 participants) and the environmental scenario (73 participants), according to level of support to the use of animals using a Likert scale, November 2008 to April 2009. Biomedical scenario: question 1, use of non-genetically modified (non-GM) pig; question 2, creation of a GM pig; question 3, use of GM pig. Environmental scenario: question 1, use of non-GM pig; question 2, use of GM corn; question 3, creation of GM pig

\section{Qualitative results}

Participants provided a total of 307 comments, 141 in BS and 166 in ES.

\section{Animal-based motivation}

Many of the comments (33\%) across both scenarios were based on concerns about animals (Table 1). Half of the conditional decisions cited welfare concerns. Some of these cited general concerns, relevant to both scenarios, such as reducing pain and suffering of animals or regarding the conditions in which animals were kept. For example, one participant wrote: 'I think that when we use animals to the benefit of humans, we should first consider the needs of the animals. If they are to (involuntarily) give their lives for us, these pigs should have an appropriate environment to express their natural behaviour. They must have proper feed and everything to provide them with a happy life, and not be locked in bad and small places, without adequate structure'. Some participants referred to the rights of the pigs (3\% of all comments). For example, participants suggested that humans do not have the right to genetically modify animals or treat them as 'slaves'. Participants spoke of the rights of animals to be respected and to have freedom. One participant based their concern on a belief in sentience of pigs: 'Pigs are similar to human beings. They are sentient: can feel pain, frustration and pleasure. This means that these animals have value and also have some rights, we cannot use them solely for our benefit'. Concerns about pain have figured prominently in earlier studies of public attitudes towards animal research (HAGELIN et al., 2003; LUND et al., 2014). These quotes illustrated the importance of welfare concerns in people's willingness to support animal research. Requiring and documenting compliance with high welfare standards, including pain prevention, is thus likely to improve public acceptance of animal use. Information regarding compliance is typically unavailable to the public in Brazil (SILLA et al., 2009). Typically, this documentation would be responsibility of governing bodies such as the Animal Ethics Committee. Governance structures were rarely mentioned in the responses, suggesting a lack of awareness or a lack of trust in their ability to ensure high welfare for the research animals. 
Table 1 - Themes and sub-themes raised in the 307 comments provided by 151 Brazilian participants answering questions about the proposed use of pigs in research, from November 2008 to April 2009. The percentages of comments that referenced the specific theme and sub-theme are shown separately for the question involving the use of pigs in an environmental research scenario and in a biomedical research scenario - 2008 - 2009

\begin{tabular}{|c|c|c|c|c|}
\hline Themes & Key words & Enviro. $(\%)^{\mathrm{b}}$ & Biomed. $(\%)^{b}$ & Total $(\%)^{c}$ \\
\hline \multirow[t]{8}{*}{ Animal-based } & & $72(48.6)$ & $76(51.4)$ & $148(32.6)$ \\
\hline & Animal welfare & $56(37.8)$ & $54(36.5)$ & $110(24.2)$ \\
\hline & Animal rights & $5(3.4)$ & $7(4.7)$ & $12(2.6)$ \\
\hline & Consequences to animals & $2(1.4)$ & $2(1.4)$ & $4(0.9)$ \\
\hline & IACUC evaluation & $2(1.4)$ & $5(3.4)$ & $7(1.5)$ \\
\hline & It is not animal ill-treatment & $3(2.0)$ & $1(0.7)$ & $4(0.9)$ \\
\hline & No to animal use & $4(2.7)$ & $3(2.0)$ & $7(1.5)$ \\
\hline & Others & $0(0.0)$ & $4(2.7)$ & $4(0.9)$ \\
\hline \multirow[t]{6}{*}{ Research } & & $46(48.9)$ & $48(51.1)$ & $94(20.7)$ \\
\hline & Decrease environmental damage & $11(11.7)$ & $0(0.0)$ & $11(2.4)$ \\
\hline & In favor of research animal use & $5(5.3)$ & $6(6.4)$ & $11(2.4)$ \\
\hline & Need for research & $25(26.6)$ & $27(28.7)$ & $52(11.5)$ \\
\hline & Research quality & $3(3.2)$ & $12(12.8)$ & $15(3.3)$ \\
\hline & Others & $2(2.1)$ & $3(3.2)$ & $5(1.1)$ \\
\hline \multirow[t]{6}{*}{ GM } & & $49(80.3)$ & $12(19.7)$ & $61(13.4)$ \\
\hline & Doubts about GM consequences & $21(34.4)$ & $0(0.0)$ & $21(4.6)$ \\
\hline & In favor of GM & $5(8.2)$ & $0(0.0)$ & $5(1.1)$ \\
\hline & No to GM / GM food / GM animal & $10(16.4)$ & $5(8.2)$ & $15(3.3)$ \\
\hline & Risks of GM & $13(21.3)$ & $3(4.9)$ & $16(3.5)$ \\
\hline & Other & $0(0.0)$ & $4(6.6)$ & $4(0.9)$ \\
\hline \multirow[t]{6}{*}{ Philosophical } & & $23(39.7)$ & $35(60.3)$ & $58(12.8)$ \\
\hline & Anthropocentrism & $12(20.7)$ & $23(39.7)$ & $14(3.1)$ \\
\hline & Humans should decrease consumption & $4(6.9)$ & $0(0.0)$ & $4(0.9)$ \\
\hline & Abolitionism & $6(10.3)$ & $0(0.0)$ & $6(1.3)$ \\
\hline & Utilitarianism & $0(0.0)$ & $6(10.3)$ & $6(1.3)$ \\
\hline & Other & $1(1.7)$ & $6(10.3)$ & $7(1.5)$ \\
\hline \multirow[t]{3}{*}{ Alternatives } & & $23(59.0)$ & $16(41.0)$ & $39(8.6)$ \\
\hline & Search for alternatives & $23(59.0)$ & $15(38.5)$ & $38(8.4)$ \\
\hline & There is no alternative & $0(0.0)$ & $1(2.6)$ & $1(0.2)$ \\
\hline \multirow[t]{3}{*}{ Numbers } & & $16(47.1)$ & $18(52.9)$ & $34(7.5)$ \\
\hline & Animal number (low, high or ok) & $16(47.1)$ & $15(44.1)$ & $31(6.8)$ \\
\hline & Animal number (others) & $0(0.0)$ & $3(8.8)$ & $3(0.7)$ \\
\hline \multirow[t]{4}{*}{ Other } & & $13(65.0)$ & $7(35.0)$ & $20(4.4)$ \\
\hline & Answer based on advisor(s) & $5(25.0)$ & $2(10.0)$ & $7(1.5)$ \\
\hline & Risks to human health & $7(35.0)$ & $3(15.0)$ & $10(2.2)$ \\
\hline & Others & $1(5.0)$ & $2(10.0)$ & $3(0.7)$ \\
\hline Total & & $242(53.3)$ & $212(46.7)$ & $454(100)^{\mathrm{a}}$ \\
\hline
\end{tabular}

${ }^{a}$ Note that 307 comments presented 454 ideas as classified by best broad categories, since more than one idea could be present in each comment. Topics that appeared less than 3 times were classified as others in each theme. ${ }^{b}$ Percentages in relation to the total of comments within each theme on both scenarios. Results of topics are the percentages within each theme. ${ }^{c}$ Percentages in relation to total of comments (454)

\section{Emphasis on research}

The need for research was identified by supporters of animal use in both scenarios ( $21 \%$ of comments). In the ES, people justified support on the basis of the importance of widespread environmental benefits to many people within society; and in the BS, comments included the benefit to humans, including improvements to human health. About $17 \%$ argued that appropriate methods are required to 
avoid doing research "in vain". Schuppli et al. (2013) also found that participants raised concerns about scientific validity, mainly regarding the choice of species and number of animals. These concerns about poor study design rendering animal use of little value may be well founded. Kilkenny et al. (2009) identified a number of issues that could compromise the quality of research using animals, such as hypothesis and objective not clearly defined, poor identification of species and number of animals used, inappropriate experimental design or statistical method, and inconsistency on reporting results.

\section{Genetic modification}

This theme was cited in $13 \%$ of the comments (Table 1). Most of these comments (80\%) arose in the ES and mostly related to the fear of consequences or risks associated with modification. Some comments specifically highlighted concern about the possibility that GM animals could end up in the human food chain. Previous work found that people often fear genetic modification of food (GASKELL et al., 2006; KNIGHT, 2006) and that non-food GM products are more accepted (CHRISTOPH et al., 2008). Some respondents commented that they did not have enough knowledge about genetic modification to know if this was safe and expressed concerns in the form of 'risks', including unintentional and unpredictable negative consequences to the environment. The majority of respondents did not mention what kind of risk they were worried about, but a few comments identified health risks like cancer and allergy. For the BS, respondents generally provided no real reason for their opposition, and instead just affirmed their antiGM stance. Even when individuals perceive some benefits from genetically modified foods, these feelings are generally less intense than the fear of unknown consequences, perhaps explaining the lack of acceptance (COSTA-FONT; MOSSIALOS, 2007). GM product acceptance may be more difficult since, as demonstrated by Frewer et al. (2004) and Deckers (2005), education and more information does not increase support for GM.

\section{Philosophical arguments}

About $13 \%$ of comments attested some kind of philosophical argument or concern, including anthropocentrism, utilitarianism, and abolitionism (Table 1). Conflicts between animal use and human benefits appeared in both scenarios and considerations were given about the price of progress and animal suffering versus environmental gain, e.g. 'I support the research, but I am not insensitive to the pigs. But I imagine if my father, mother, son or husband - or even I - needed this technology. Egotism, perhaps, but if some limits were established and respected, technology would not be that monstrous'. Comments on abolition of pig farming and reduction of consumption were present only in the ES (2\% of all comments). The problem of agricultural pollution was considered as the direct result of animal farming.

\section{Alternatives and new paradigms}

The need for alternatives was mentioned in $8 \%$ of the comments. In the BS, respondents often mentioned the need for alternatives in relation to comments regarding the number of animals, but in the ES it was more frequently related to risks of GM, animal welfare and abolitionism. Interestingly, participants did not raise concerns around the need for alternative approaches in the BS when the use of non-GM animals was proposed. Knight and Barnett (2008) identified that support of some participants for the use of animals in medical research was based upon the belief that there were no suitable alternatives to using animals. Greek et al. (2010) concluded that people are more likely to support the use of animals if the research is likely to aid in the treatment and decrease the suffering of human patients, but that people are less likely to support animal use in basic research. This type of reasoning may figure in the utilitarian calculus of many participants, who see the life of a human patient as more valuable than one of a pig. We suggest that research is needed to test the limits of this reasoning.

In summary, many Brazilian respondents were willing to support the use of animals in research, but this support was often conditional upon adequate protection of the animals' welfare. Participants were less willing to support research when this involved the creation of GM animals, partly because they feared the risk associated with this technology. More research on public opinion regarding the support to the use of animals in research and the use of GM animals for different purposes in Brazil is welcome, given the intensification of animal research in the country and the paucity of specific Brazilian literature on this topic. It is also desirable that more information about the use of animals in research in Brazil become available to citizens, in order to give transparency to the scientific merit and the animal welfare issues involved. 


\section{Acknowledgements}

This work was supported by Genome Canada and Genome BC (Building a GE3LS Architecture Project 2006-2009); and the Brazilian funding agencies PIBIC/

\section{References}

BONES, V. C.; CLEMENTE, H. C.; WEARY, D. M.; MOLENTO, C. F. Perceived barriers to the adoption of alternatives to laboratory animal use for rabies diagnosis. Alternatives to Laboratory Animals, v. 42, n. 3, p. 171-179, 2014. Available from: $<$ https://goo.gl/dNvGvO $>$. Viewed: 19 June 2015.

BRASIL. Lei no 9.605, de 12 de fevereiro de 1998. Dispõe sobre as sanções penais e administrativas derivadas de condutas e atividades lesivas ao meio ambiente, e dá outras providências. Diário Oficial da União, Poder Executivo, Brasília, DF, 13 Feb. 1998. Seção 1, p. 1.

BRASIL. Lei $\mathrm{n}^{\circ} 11.794$, de 8 de outubro de 2008. Regulamenta o inciso VII do $\$ 1$ o do art. 225 da Constituição Federal, estabelecendo procedimentos para o uso científico de animais; revoga a Lei no 6.638, de 8 de maio de 1979; e dá outras providências. Diário Oficial da União, Poder Executivo, Brasília, DF, 9 Oct. 2008. Seção 1, p. 1.

CARVALHO, E. B.; MAGA, E. A.; QUETZ, J S.; LIMA, I F.; MAGALHAES, H. Y.; RODRIGUES, F. A.; SILVA, A. V.; PRATA, M. M.; CAVALCANTE, P. A.; HAVT, A.; BERTOLINI, M.; BERTOLINI, L. R.; LIMA, A. A. Goat milk with and without increased concentrations of lysozyme improves repair of intestinal cell damage induced by enteroaggregative Escherichia coli. BMC Gastroenterology, v. 12, n. 1, p. 106, 2012. doi: 10.1186/1471230X-12-106.

CHRISTOPH, I. B.; BRUHN, M.; ROOSEN, J. Knowledge, attitudes towards and acceptability of genetic modification in Germany. Appetite, v. 51, n. 1, p. 58-68, 2008. doi: 10.1016/j.appet.2007.12.001.

COSTA-FONT, J.; MOSSIALOS, E. Are perceptions of "risks" and "benefits" of genetically modified food (in) dependent? Food Quality and Preference, v. 18, n. 2, p. 173-182, 2007. doi: 10.1016/j.foodqual.2005.09.013.
CNPq (Institutional Scientific Initiation Scholarship Program/National Counsel of Technological and Scientific Development) and CAPES (Coordination for the Improvement of Higher Education Personnel).

CRETTAZ VON ROTEN, F. European attitudes towards animal research: overview and consequences for science. Science, Technology and Society, v. 14, n. 2, p. 349-364, 2009. doi: $10.1177 / 097172180901400207$.

CRETTAZ VON ROTEN, F. Public perceptions of animal experimentation across Europe. Public Understanding of Science, v. 22, n. 6, p. 691-703, 2012. doi: 10.1177/0963662511428045.

DECKERS, J. Are scientists right and non-scientists wrong? Reflections on discussions of GM. Journal of Agricultural and Environmental Ethics, v. 18, n. 5, p. 451-478, 2005. doi: 10.1007/s10806-005-0902-1.

EUROPEAN COMMISSION. Biotechnology: report. Special Eurobarometer, n. 341. Brussels: European Commission, 2010a.

EUROPEAN COMMISSION. Sixth report on the statistics on the number of animals used for experimental and other scientific purposes in the member states of the European Union. Brussels: European Commission, 2010b. Available from: <https://goo.gl/7DyZzg $>$. Viewed: 19 June 2017.

FRANZEN, A.; MEYER, R. Environmental attitudes in cross-national perspective: a multilevel analysis of the ISSP 1993 and 2000. European Sociological Review, v. 26, n. 2, p. 219-234, 2010. doi: 10.1093/esr/jcp018.

FREWER, L.; LASSEN, J.; KETTLITZ, B.; SCHOLDERER, J.; BEEKMAN, V.; BERDAL, K. G. Societal aspects of genetically modified foods. Food and Chemical Toxicology, v. 42, n. 7, p. 1181-1193, 2004. doi: 10.1016/j. fct.2004.02.002.

GASKELL, G.; ALLANSDOTTIR, A.; ALLUM, N.; CORCHERO, C.; FISCHLER, C.; HAMPEL, J.; JACKSON, J.; KRONBERGER, N.; MEJLGAARD, 
N.; REVUELTA, G.; SCHREINER, C.; STARES, S.; TORGERSEN, H.; WAGNER, W. Europeans and Biotechnology in 2005: patterns and trends. Brussels: European Commission, 2006.

GREEK, R.; GREEK, J. Is the use of sentient animals in basic research justifiable? Philosophy, Ethics and Humanities in Medicine, v. 5, n. 1, p. 14, 2010. doi: 10.1186/1747-5341-5-14.

HAGELIN, J.; CARLSSON, H.; HAU, J. An overview of surveys on how people view animal experimentation: some factors that may influence the outcome. Public Understanding of Science, v. 12, n. 1, p. 67-81, 2003. doi: $10.1177 / 0963662503012001247$.

IPSOS MORI. Views on the use of animals in scientific research. London: Ipsos Mori, 2012.

KILKENNY, C.; PARSONS, N.; KADYSZEWSKI, E.; FESTING, M. F. W.; CUTHILL, I. C.; FRY, D.; HUTTON, J.; ALTMAN, D. G. Survey of the quality of experimental design, statistical analysis and reporting of research using animals. PLoS One, v. 4, n. 11, p. e7824, 2009. doi: 10.1371/ journal.pone.0007824.

KNIGHT, A. J. Does application matter? An examination of public perception of agricultural biotechnology applications. The Journal of Agrobiotechnology Management and Economics, v. 9, n. 2, p. 121-128, 2006. Available from: <https://goo.gl/Sm62oG>. Viewed: 10 Mar. 2015.

KNIGHT, S.; BARNETT, L. Justifying attitudes toward animal use: a qualitative study of people's views and beliefs. Anthrozoös, v. 21, n. 1, p. 31-42, 2008. doi: $10.2752 / 089279308 X 274047$.

LUND, T. B.; LASSEN, J.; MØRKBAK, M. R.; SANDØE, P. Painful dilemmas: a study of the way the public's assessment of animal research balances costs to animals against human benefits. Public Understanding of Science, v. 23, n. 4, p. 428-444, 2014. doi: 10.1177/0963662512451402.
OLFERT, E. D.; CROSS, B. M.; MCWILLIAM, A. A. Guide to the care and use of experimental animals. Ottawa: Canadian Council on Animal Care, 1993. v. 1.

ORMANDY, E. H.; SCHUPPLI, C. A.; WEARY, D. M. Worldwide trends in the use of animals in research: the contribution of genetically-modified animal models. Alternatives to Laboratory Animals, v. 37, n. 1, p. 63-68, 2009. Available from: <https://goo.gl/AxzccI $>$. Viewed: 11 June 2015.

PALYS, T. S. Research decisions: quantitative and qualitative perspectives. Scarborough, CA: Thomas Nelson, 2003.

ROLLIN, B. E. Farm animal welfare: social, bioethical and research issues. Iowa City: Iowa State Press, 2003.

SCHUPPLI, C.; MOLENTO, C. F. M.; WEARY, D. M. Understanding attitudes towards the use of animals in research using an online public engagement tool. Public Understanding of Science, v. 24, n. 3, p. 1-17, 2013. doi: $10.1177 / 0963662513490466$.

SILLA, V. C. B.; MARTHOS, S. M.; MOLENTO, C. F. M. Descrição de dois anos de atuação da Comissão de Ética no Uso de Animais do Setor de Ciências Agrárias da Universidade Federal do Paraná. Ciência Rural, v. 39, n. 7, p. 2093-2098, 2009. doi: 10.1590/S0103-84782009000700021.

SILLA, V. C. B.; SANS, E. C. O.; MOLENTO, C. F. M. An estimation of the extent of animal use in research in Brazil, as determined by bibliographic sampling from journals published in the State of Paraná. Alternatives to Laboratory Animals, v. 38, n. 1, p. 29-37, 2010. Available from: <https://goo.gl/PVgjzV>. Viewed: 13 Dec. 2014.

TAYLOR, K.; GORDON, N.; LANGLEY, G.; HIGGINS, W. Estimates for worldwide laboratory animal use in 2005. Alternatives to Laboratory Animals, v. 36, p. 327-342, 2008. Available from: $<$ https://goo.gl/9TWlZR $>$. Viewed: 13 Sept. 2015. 